\title{
Effects of Soil-Applied Fungicides on Sugarcane Root and Shoot Growth, Rhizosphere Microbial Communities, and Nutrient Uptake
}

\author{
Murali Vuyyuru, Hardev S. Sandhu *, James M. McCray and Richard N. Raid \\ Everglades Research and Education Center, University of Florida, 3200 East Palm Beach Road, \\ Belle Glade, FL 33430, USA; m.vuyyuru@ufl.edu (M.V.); jmmccray@ufl.edu (J.M.M.); rnraid@ufl.edu (R.N.R.) \\ * Correspondence: hsandhu@ufl.edu; Tel.: +1-561-993-1500
}

Received: 29 August 2018; Accepted: 6 October 2018; Published: 9 October 2018

check for updates

\begin{abstract}
Sugarcane (Saccharum spp. hybrid) successive planting (also called monoculture) causes serious yield losses and its management is not well studied in Histosols. Based on very few studies in other sugarcane regions, root colonization by harmful soil fungi is considered as a major cause of this yield decline, but there is lack of knowledge on its management in Histosols. A two-year greenhouse study was conducted with soil-drench application of mancozeb, mefenoxam, and azoxystrobin fungicides to determine their effects on early root and shoot growth, soil microbial communities, and nutrient uptake by plants. The study indicated that mancozeb soil application improved sugarcane-shoot and -root dry matter by 3-4 times and shoot-root length, fine-root length, and root surface area by 2-3 times compared to untreated soil. Phospholipid fatty acid (PLFA) analyses of sugarcane rhizosphere soil showed significant reduction in fungal-biomarker abundance with mancozeb and azoxystrobin in comparison to the untreated check or mefenoxam treatments. Bacterial functional-group abundance was reduced by mancozeb and mefenoxam. All fungicides significantly reduced mycorrhizal colonization but not mycorrhizal spore counts. There was a functional relationship between fine-root systems and higher tissue concentration of nitrogen and silicon. The study indicated that application of fungicides to the soil may improve early root and shoot growth and plant-cane establishment that can potentially reduce the yield decline in successively planted sugarcane in histosols. Additional field research is needed in the future to determine the fungicide soil application method, sugarcane growth response in whole crop cycles, and any environmental effects.
\end{abstract}

Keywords: sugar yield decline; early root and shoot growth; root health; broad spectrum fungicides; microbial communities; soil immobile nutrient uptake

\section{Introduction}

A perennial grass, sugarcane (Saccharum spp. hybrid) experiences yield decline under prolonged monoculture (also called successive planting). Magarey [1] demonstrated that this decline is evidenced by poor root health associated with soil-borne root pathogens, many of them fungi. Poor-root-syndrome occurrence in many sugarcane-producing countries suggests the prevalence of Pythium arrhenomanes, and pathogenicity tests show severe damage to fine-root systems and reductions in shoot growth [2]. Loss of more than $80 \%$ of the primary shoot-root system weakens the structural stability of the stool, increasing the likelihood of stalks toppling over. Pythium root rot, confined to the fine-root system, does not cause a level of damage to result in toppling over. This occurs with Pachymetra primary root rot, an endemic disease to the sugarcane belt of Australia. Apart from P. arrhenomanes, several other species of Pythium, Pachymetra chaunorhiza (Pachymetra root 
rot), Rhizoctonia spp., dematiaceous or dark sterile fungi are also known to damage the sugarcane-root system [3,4]. Visible root symptoms, such as roots devoid of root hairs or the absence of a fine-root system, inhibit nutrient and water uptake and therefore reduce plant vigor. Pineapple sett-rot disease, caused by Ceratocystis paradoxa, is also reported to be more prevalent in soils with successive sugarcane planting. The pathogen attacks seed cane through the cut ends, thereby causing seed-piece decay and patchy germination [5].

Sugarcane planting or propagation is commonly vegetative, using stem cuttings that have lateral buds on each node. After planting, the growth phase starts with the emergence of sett roots from a band of root primordia above the leaf scar on the nodes of the sett. Early sett roots are finely branched roots and sustain the growing bud in the first few weeks after planting. These roots later start senescing and disappear 60 to 90 days after planting [6]. In the second growth phase, shoot roots emerge from the base of the new shoot and are typically thicker than sett roots. Finally, the shoot roots develop into the main root system of the plant. Deleterious fungi may attack the developing root system within days of planting, slowing down primary shoot growth and subsequent production and growth of secondary shoots or tillers [7,8]. Previous studies in Australia showed the application of benomyl and dithiocarbamate (mancozeb, maneb, and zineb) fungicides in monoculture soils improved sugarcane-root and -shoot growth [9]. Mancozeb dose (25-400 mg a.i. (active ingredient) $\mathrm{kg}^{-1}$ soil) response studies showed a higher rate of root-growth improvement with each increment from 25 to $100 \mathrm{mg}$ a.i. $\mathrm{kg}^{-1}$ soil, but the response was low after $100 \mathrm{mg}$ a.i. $\mathrm{kg}^{-1}$ soil [10]. The root-growth response with fungicides such as benomyl and analazin was low compared to mancozeb [11]. In Louisiana soils, $16 \%$ to $27 \%$ plant-cane and ratoon growth enhancements were observed with application of the oomycete-specific fungicide metalaxyl [12].

A healthy sugarcane-root system with numerous fine roots offers greater surface area, which will increase the diffusive supply of soil immobile nutrients. Arbuscular mycorrhizal fungi (AMF) and their symbiotic association with plant roots through the formation of extraradical hyphae also contribute to the absorption of immobile soil nutrients [13]. Histosols in the Everglades Agricultural Area (EAA) are generally low in the recommended levels of available soil phosphorus (Mehlich-3 $\mathrm{P}<40 \mathrm{mg} \mathrm{kg} \mathrm{g}^{-1}$ soil) as established for sugarcane [14]. Whenever soil $\mathrm{P}$ levels are low, mycorrhizal association is said to be beneficial in terms of supply of $\mathrm{P}, \mathrm{Cu}$ and $\mathrm{Zn}$ nutrients to the associated plant [15]. Mycorrhizae can also cause detrimental effects on plant growth during initial stages of growth as developing hyphal network continue to draw sugars from the host plant [16]. As reported by Hendrix et al. [16] and Johnson et al. [17], mycorrhizal association with sugarcane causes negative impact on plant growth whenever soil P levels are high. Research conducted on citrus seedlings with the soil application of copper, metalaxyl-M, thiobendazole fungicides, even at low concentrations, prevented mycorrhizal-fungi root colonization and subsequent growth reduction [18]. Sensitivity of AM fungi towards soil-applied fungicides was mixed, ranged from no impact to complete elimination, and reduced or increased root infections in different crops $[19,20]$.

Mancozeb (coordination product of zinc ion and manganese ethylene bis-dithocarbamate) is a broad-spectrum contact fungicide used in agriculture, turf management, and horticultural crops [21]. Mefenoxam is a systemic phenyl amide fungicide (R-enantiomer of metaloxyl) and is effective against diseases caused by Pythium spp. and Phytophtohora spp. [22]. Azoxystrobin is a systemic fungicide belonging in the strobilurin group and is used to control several pathogenic Ascomycota, Basidiomycota, Deuteromycota, and Oomycota fungi causing diseases to a wide range of crops [23]. Strobilurins are spore-germination inhibitors, known as QoI fungicides as they inhibit mitochondrial respiration by binding the quinol oxidation site and stop electron transfer between cytochrome $b$ and c [24]. Due to the systemic and broad-spectrum activity of azoxystrobin, it has been used as an in-furrow spray and in soil-drench applications in different crops at the seedling stage [25].

Management of sugarcane yield decline in successive planting is well researched in Australia [26]. There were no reports available on sugarcane-monoculture yield-decline management in Histosols. To test the efficacy of fungicides in Histosols, we hypothesized that soil-applied fungicide may reduce 
the influence of detrimental fungal root pathogens, thereby enhancing root health. This would be reflected in greater shoot biomass and uptake of nutrients in the soil such as nitrogen, phosphorus, copper, zinc, iron, and silicon. The specific objectives of the study were: (i) to determine the effects of soil-applied fungicides on early root and shoot growth of sugarcane; (ii) to understand the effect of soil-applied fungicides on rhizosphere microbial communities and on the mycorrhizal colonization of roots; and iii) to determine the uptake of immobile soil nutrients as an indicator of a healthy or weak fine-root system of the sugarcane plant.

\section{Materials and Methods}

\subsection{Pot Experiment Setup}

A two-year (2016 and 2017) greenhouse study was conducted at the EREC (Everglades Research and Education Center), Belle Glade, Florida to determine the effect of fungicides on soil early plant growth and soil properties. Identical experimental and data-collection procedures were used during both years, with the second year (2017) being a repetition of first trial (2016). The soil used in this study was obtained from a sugarcane field that was under a long-term ( $>20$ years) monoculture. Located at the EREC experimental farm, Belle Glade, Florida, the soil type was Histosol or Pahokee series muck (euic, hyperthermic Lithic Haplosaprist) with a pH of 7.4, 82\% of organic matter, 2.3\% of N, 46 ppm of P, 112 ppm of K, 7.19 ppm of $\mathrm{Cu}, 1.05$ ppm of Mn, 32.5 ppm of Zn, 14 ppm of Fe, $20 \mathrm{ppm}$ of $\mathrm{Si}$, and $277 \mathrm{ppm}$ of $\mathrm{S}$. topsoil (0-15 cm depth) was excavated from an area adjacent to the stubble region and was passed through a $4 \mathrm{~mm}$ sieve. Plastic pots $(1.7 \mathrm{~L} ; 15.8 \mathrm{~cm}$ diameter $\times 15.0 \mathrm{~cm}$ depth) were uniformly filled with $1.25 \pm 0.05 \mathrm{~kg}$ of field-moist soil (dry bulk density, $0.38 \mathrm{~g} \mathrm{~cm}^{3}$ ) in each pot. All pots were fertilized with a nutrient mix at $450 \mathrm{mg} \mathrm{pot}^{-1}$, containing $3.05 \%$ of $\mathrm{P}, 21.58 \%$ of $\mathrm{K}, 31.73 \%$ of $\mathrm{S}, 0.88 \%$ of $\mathrm{Mn}, 0.24 \%$ of $\mathrm{Cu}, 0.30 \%$ of $\mathrm{Zn}$, and $0.12 \%$ of $\mathrm{B}$, respectively. Fertilizer rates were calculated based on the surface area of each pot and established soil test-based nutrient recommendations for sugarcane grown on Histosols in Florida [27]. Single-budded seed pieces (with a $2 \mathrm{~cm}$ stalk on either side), obtained from the middle of mature stalks of the sugarcane cultivar $\mathrm{CP}$ 96-1252 [28] were first planted in greenhouse flat trays $(27.5 \mathrm{~cm}$ width $\times 53.5 \mathrm{~cm}$ length $\times 7.0 \mathrm{~cm}$ depth) to ensure uniformity in germination before transplanting to the pots. We used double the number of single-budded cuttings than required for transplanting into the pots. Each tray was planted with 25 buds and 6 trays were used per each treatment. At 3 weeks after planting, similarly sized seedlings were selected and transplanted to pots with one seedling per pot. The study was conducted during both years during sugarcane-planting season (October to mid January), and inside greenhouse temperature during the day was $32-38{ }^{\circ} \mathrm{C}, 22-25^{\circ} \mathrm{C}$ at night, with a relative humidity of $60 \%$.

\subsection{Fungicides Application}

Commercial formulations of mancozeb at $250 \mu \mathrm{g} \mathrm{mL}{ }^{-1}$ (Manzate ${ }^{\circledR} 75 D F$, Griffin L.L.C, Valdosta, GA, USA), azoxystrobin at $30 \mu \mathrm{g} \mathrm{mL}{ }^{-1}$ (Quadris $^{\circledR} 2.08 \mathrm{SC}$, Syngenta Corporation, Greensboro, NC, USA), mefanoxam at $55 \mu \mathrm{g} \mathrm{mL}^{-1}$ (Ridomil Gold ${ }^{\circledR} 2 \mathrm{E}$, Syngenta Corporation, Greensboro, NC, USA) in $200 \mathrm{~mL}$ of water were applied as soil drench in each pot. The untreated pots were drenched only with $200 \mathrm{~mL}$ water. The use of $200 \mathrm{~mL}$ water was based on the preliminary test that was conducted to estimate the amount of water needed to drench the soil in one pot. Fungicide concentrations were calculated based on the surface area of the pots compared to the fungicide-treated surface area in a one-hectare application rate in the field (Table 1). In field, the fungicide is normally applied in a $0.15 \mathrm{~m}$ wide band in each furrow with $1.5 \mathrm{~m}$ inter-furrow spacing. So, the total fungicide-treated area in one hectare was considered to be $\left(10,000 \mathrm{~m}^{2} / 1.5 \mathrm{~m}\right) \times 0.15 \mathrm{~m}=1000 \mathrm{~m}^{2}$ in calculating fungicide concentration for the pots. There were 75 pots in each treatment (total 300 pots in 4 treatments) that were arranged in a completely randomized design on greenhouse benches. Soil used in the flat trays for seed-piece germination was treated with fungicides at $1.5 \times$ times the concentration used in those of pots in $1 \mathrm{~L}$ drench volume. As mancozeb contains $15 \%$ of $\mathrm{Mn}$ and $1.9 \%$ of $\mathrm{Zn}$, the other treatments 
were compensated for these nutrients through fertilization. After fungicide application, a thin layer of soil was spread over the top of the pot or tray to reduce evaporation losses.

Table 1. Trade name, active ingredient, and concentrations, IUPAC (International Union of Pure and Applied Chemistry) name and furrow application rate of different fungicides used in the study.

\begin{tabular}{|c|c|c|c|}
\hline Trade Name & $\begin{array}{l}\text { Active Ingredient and } \\
\text { Concentration }(\%)\end{array}$ & IUPAC Name & $\begin{array}{l}\text { Application Rate } \\
\left(\mathrm{kg} \mathrm{a.i} \mathrm{ha}^{-1}\right)^{\S}\end{array}$ \\
\hline Manzate $^{\circledR} 75$ DF & Mancozeb 75\% & $\begin{array}{l}\text { Manganese ethylene bis-dithiocarbamate } \\
\text { polymeric ion complex with zinc salt }(1.9 \%)\end{array}$ & 2.55 \\
\hline Ridomil Gold ${ }^{\circledR} 2 \mathrm{E}$ & Mefenoxam $45.3 \%$ & $\begin{array}{l}\{(R, S)-2-((2,6 \text {-dimethylphenyl)-methoxy } \\
\text { acetylamino)-propionic acid methyl ester }\}\end{array}$ & 0.570 \\
\hline Quadris $^{\circledR} 2.08 \mathrm{SC}$ & Azoxystrobin $22.9 \%$ & $\begin{array}{c}\text { Methyl (2E)-2-(2-\{(6-(2-cyanophenoxy) } \\
\text { pyrimidin-4-yl) } \\
\text { oxy\}phenyl)-3-methoxyacrylate }\end{array}$ & 0.296 \\
\hline
\end{tabular}

spaced cane rows in the field and not based on the whole area. a.i: active ingredient;

\subsection{Growth Measurements}

Emergence percentage was estimated by counting the number of buds that emerged from the greenhouse flat trays, and the rest of the growth measurements were conducted after transplanting the seedlings in pots. Primary shoot length was measured from the plant base to the base of the top visible dewlap (TVD) leaf. The total number of primary, secondary, and tertiary shoots (also called tillers) were counted until final harvest (at 105 days after planting, (DAP)) of the experiment. Plants were harvested after 30, 52, 70, 90, and 105 DAP to measure root and shoot growth. At each harvest, 10 randomly selected plants were carefully uprooted without damaging the root system. Set roots and shoot roots were separated at 30,52,70, and $90 \mathrm{DAP}$, while at $105 \mathrm{DAP}$, set roots could not be separated from shoot roots because of their very small proportion compared to shoots roots. Roots were washed on a $2 \mathrm{~mm}$ mesh screen to remove adhering soil particles. The washed-root images were acquired on greyscale at a resolution of 800 dpi with the help of an Epson LA 2400 flatbed scanner (Epson America, Inc., Long Beach, CA, USA) equipped with an overhead transparency unit (TPU) and a special lighting system to prevent any potential shadows while scanning. The set- and shoot-root lengths, surface area, and root diameters were determined from the scanned root images using WinRHIZO regular ${ }^{\mathrm{TM}} 2016$ (Regent Instruments, Québec, QC, Canada) root image-analysis software. For a better understanding of the fine roots, root diameter classes were set at $0.2 \mathrm{~mm}$ class interval. The class with $<0.2 \mathrm{~mm}$ diameter were considered as fine roots to determine their relationship with tissue centration and uptake of less-mobile nutrients in the soil. Roots and shoots were dried for $72-80 \mathrm{~h}$ at $70{ }^{\circ} \mathrm{C}$ in a hot-air oven until constant mass was achieved. Root:shoot ratio, total biomass, and root:total biomass ratios were calculated on a constant oven-dry weight basis.

\subsection{Phospholipid Fatty Acid (PLFA) Analyses}

After 70 days of growth, 16 plants were uprooted from each treatment and roots were shaken vigorously and gently rubbed against each other in a sterile whirl-pak bag (Nasco, whirlpak ${ }^{\mathrm{TM}}$, Fort Atkinson, WI, USA) to collect rhizosphere soil. The rhizosphere soil from 4 plants was combined in 1 composite sample with a total of 4 replicates, and microbial community analysis was performed by following a high-throughput PLFA procedure for soils [29]. One gram of freeze-dried soil was extracted with a Bligh-Dyer solution added with internal standard (19:0 phosphatidylcholine, Avanti Polar Lipids, Inc. Alabaster, AL, USA). Phospholipids were separated from neutral and glycolipids classes by solid-phase extraction (SPE) using a 96-well SPE plate preloaded with $50 \mathrm{mg}$ silica per well. Phospholipids were eluted with $0.5 \mathrm{~mL}$ of 5:5:1 methanol:chloroform:water into $1.5 \mathrm{~mL}$ glass vials. Phospholipids were trans-esterified by adding $200 \mu \mathrm{L}$ of a reagent mixture containing potassium hydroxide $(\mathrm{KOH})$; methanol and toluene. PLFAs were extracted with hexane and analyzed by gas chromatography (Hewlett Packard 6890 series gas chromatograph, Agilent Technologies 
Inc., Santa Clara, CA, USA). Different peaks in the chromatograph were identified with the MIDI PLFAD1 (MIDI labs Inc., Newark, DE, USA) calibration mix and peak naming table. Individual PLFA biomarkers ( $\mathrm{n}$ mole $\mathrm{g}^{-1}$ dry soil) were assigned to different functional groups of microorganisms. The PLFA biomarkers were the sum of PLFAs i15:0, a15:0, i16:0, i17:0, and a17:0 for Gram + ve bacteria [30,31], sum of cy17:0, 16:1 $\omega 7,18: 1 \omega 7$, and 17:1 $\omega 9$ for Gram - ve bacteria [32], and sum of 10Me16:0, 10Me17:0, and 10Me18:0 for Actinomycetes [33]. The fungal biomarkers included 18:2w6 for fungi [34] and 16:1 $\omega 5$ for arbuscular mycorrhizal fungi [35]. Total bacteria were expressed as the sum of Gram + ve bacteria, Gram - ve bacteria, and Actinomycetes. The fungi to bacteria ratio was expressed by dividing the fungal biomarker $(18: 2 \omega 6)$ with total bacteria [36].

\subsection{Mycorrhizal Spore Density and Root-Colonization Studies}

Pot experiments with the soil application of fungicides involving initial growth studies are difficult to conclude without mycorrhizal association studies. In the present study, we included mycorrhizal colonization (\%) of roots and spore counts primarily to know any possible suppression or increased root colonization and sporulation after the soil-drench application of fungicides. In the follow-up experiment in 2017, at 70 DAP, 20 plants were randomly selected from each treatment and composited to 4 replicates to conduct the mycorrhizal-colonization and spore-count studies. Root infections by mycorrhizal fungi were determined by loading root subsamples into a tissue cassette (Fisher Scientific, Pittsburgh, PA, USA). These tissue samples were immersed in $10 \% \mathrm{KOH}$ and autoclaved at $110{ }^{\circ} \mathrm{C}$ for $3 \mathrm{~min}$. After brief cooling, the roots were bleached with clorox and thoroughly rinsed to remove $\mathrm{KOH}$ and clorox residues. Cassettes were soaked in $1 \% \mathrm{HCl}$ and kept overnight in $0.05 \%$ trypan blue for staining [37]. The stained roots were cut into $1 \mathrm{~cm}$ pieces and mounted in batches of 10 on microscopic slides to observe under a compound microscope at $10 \times$ and $40 \times$ magnifications. The extent of mycorrhizal colonization was visually determined according to the root-slide method [38] with a Leica DM300 compound microscope (Leica Microsystems Inc. Buffalo Grove, IL, USA). Mycorrhizal spore counts were conducted by wet sieving $10 \mathrm{~g}$ of soil followed by centrifugation in sucrose $[39,40]$. Spore identification was based on mycorrhizal-spore pictures showing thick-walled chlamydospores that are produced by Glomus spp. These spores were further categorized based on morphological features such as size, shape, and wall-ornamentation characters and compared with standard specimens of Glomus spp. [41].

\subsection{Nutrient Uptake}

Shoots of 5 potted plants were composited in each replicate (with a total of 4 replicates) for tissue-nutrient composition. Shoots were dried at $70{ }^{\circ} \mathrm{C}$ for 4 to 6 days in a hot-air oven until constant weight was attained. Oven-dried tissues were ground in a Willey plant-tissue grinding mill (Thomas Scientific, Swedesboro, NJ, USA) fitted with a $1 \mathrm{~mm}$ sieve and were used for nutrient-concentration determination. Total Kjeldahl Nitrogen (TKN) concentration of tissue samples was obtained by digesting $0.10 \mathrm{~g}$ of the ground tissue with $3.5 \mathrm{~mL}$ concentrated $\mathrm{H}_{2} \mathrm{SO}_{4}$ and $1.0 \mathrm{~g}$ Kjeldahl digestion mixture $\left(10 \mathrm{~g} \mathrm{~K}_{2} \mathrm{SO}_{4}+0.30 \mathrm{~g} \mathrm{CuSO}_{4}\right)$ for $3.5 \mathrm{~h}$ at $160{ }^{\circ} \mathrm{C}$ to $380{ }^{\circ} \mathrm{C}$ temperature in a block digester. TKN content was determined by following the semiautomated colorimetric analytical procedure in the digested samples by method 351.2 [42]. Tissue $\mathrm{P}, \mathrm{Mg}, \mathrm{Zn}, \mathrm{Cu}$, and $\mathrm{Fe}$ were determined after ashing $0.4 \mathrm{~g}$ of the ground sample at $500{ }^{\circ} \mathrm{C}$ for $12 \mathrm{~h}$ [43]. The ash was dissolved in $2 \mathrm{~mL}$ of $6.0 \mathrm{M} \mathrm{HCl}$ and concentration of elements in the extraction was determined by inductively coupled plasma-emission spectrometer (Agilent 5110 ICP-OES, Santa Clara, CA, USA). Silicon concentration of tissues was determined by following the colorimetric procedure after autoclave-induced digestion [44]. Stunted plants are likely to have greater nutrient concentration, and to overcome possible nutrient dilution with higher growth achieved in fungicide-treated plants, nutrient uptake was also included in the study. 


\subsection{Statistical Analyses}

Statistical analyses were performed using SAS statistical software (SAS 9.4, SAS Institute Inc., Cary, NC, USA). Proc univariate was used to test the normality and homogeneity of variance assumptions of ANOVA (Analysis of variance) with normal P-P and Q-Q plots. Data on shoot- and root-growth measurements, collected during both years, were combined, as the variance was homogeneous. Proc GLM was performed to compare the effect of treatments on various parameters measured in the study. Multiple comparisons of post-hoc pairwise treatment means were compared with Tukey's HSD test at $\alpha=0.05$ whenever ANOVA indicated significant differences $(p \leq 0.05)$. Allometric relationship between root and shoot biomass was visualized with simple linear regression. Pearson correlation analyses were performed to determine the relationship between mycorrhizal-spore density, root parameters with aboveground biomass, and nutrient concentrations.

\section{Results}

\subsection{Early Root and Shoot Growth}

Based on pooled data from two years, fungicide use resulted in a greater percentage of bud emergence, primary shoot height, and number of secondary shoots at $105 \mathrm{DAP}$, but differences were not always statistically significant among the fungicide treatments (Table 2). Mancozeb consistently showed significant improvement in all measured parameters compared to the untreated check. Mefenoxam had greater bud emergence and primary shoot height, while azoxystrobin only had greater primary shoot height than the untreated check. Among the tested fungicides, mancozeb had a greater primary shoot height and number of secondary shoots than others.

Table 2. Mean bud emergence, primary shoot height, and tiller production at 105 days after planting (DAP) in different fungicide treatments in pooled data from 2016 and 2017.

\begin{tabular}{cccc}
\hline Treatment & Bud Emergence (\%) & Primary Shoot Height $\mathbf{( c m )}$ & Number of Tillers \\
\hline Untreated & $65.50 \pm 1.99 \mathrm{c}$ & $17.43 \pm 0.18 \mathrm{c}$ & $0.62 \pm 0.26 \mathrm{~b}$ \\
Mancozeb & $81.75 \pm 1.75 \mathrm{a}$ & $27.25 \pm 0.49 \mathrm{a}$ & $2.00 \pm 0.01 \mathrm{a}$ \\
Mefenoxam & $80.25 \pm 2.08 \mathrm{ab}$ & $21.50 \pm 0.37 \mathrm{~b}$ & $0.87 \pm 0.29 \mathrm{~b}$ \\
Azoxystrobin & $73.25 \pm 2.23 \mathrm{bc}$ & $21.75 \pm 0.49 \mathrm{~b}$ & $1.00 \pm 0.32 \mathrm{~b}$ \\
\hline
\end{tabular}

Values followed by different letters in a column were significantly different; Tukey's Honest Significant Difference (HSD) test at $p \leq 0.05$.

Fungicide-treated plants also had higher shoot dry biomass (Figure 1a) and root dry biomass (Figure $1 b$ ) production than the untreated check, and the differences were significant from the second harvest (52 DAP) onwards. Mancozeb was most effective and produced 2-3 times greater shoot dry biomass and 4-5 times greater root dry biomass than all other fungicides and the untreated check at 105 DAP. At the first four harvests (30, 52, 70, and 90 DAP), root:shoot ratio and root:total biomass ratios were greater in fungicide treatments than the untreated check (Figure 1c,d), but at final harvest (105 DAP), only mancozeb showed higher ratios than other treatments and the untreated check. At final harvest, mancozeb increased root:shoot ratio and root:total biomass ratio by more than $40 \%$ and $30 \%$, respectively. 
(a) Shoot dry matter production

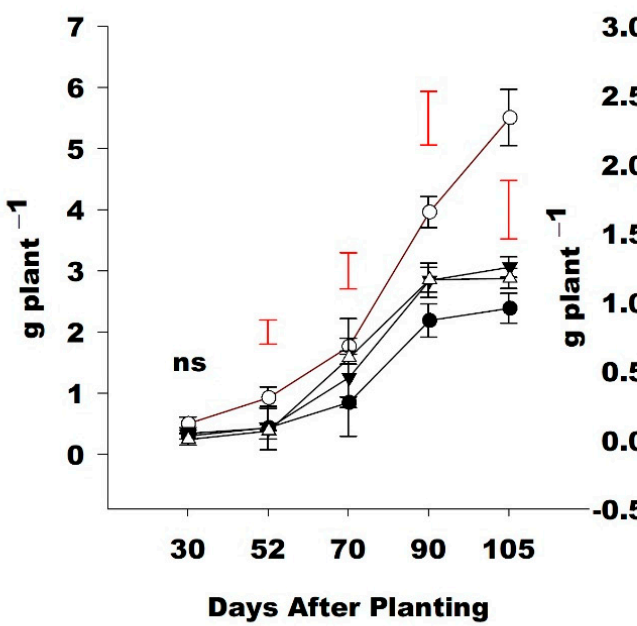

(c) Root : Shoot ratio

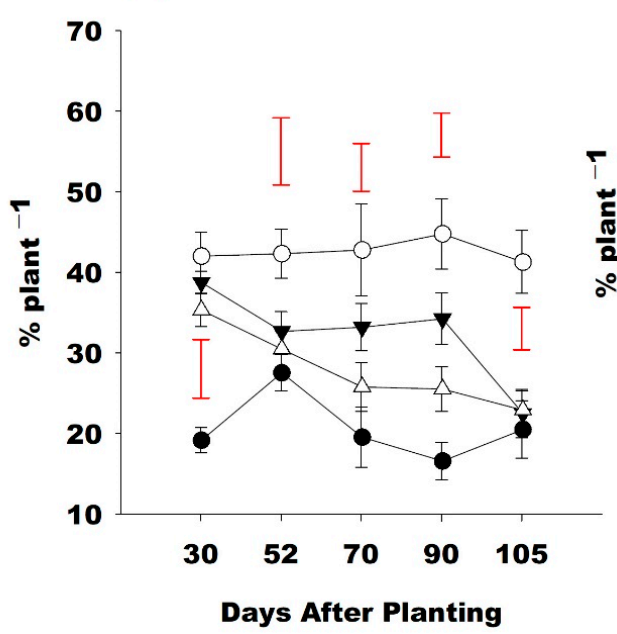

(b) Root dry matter production

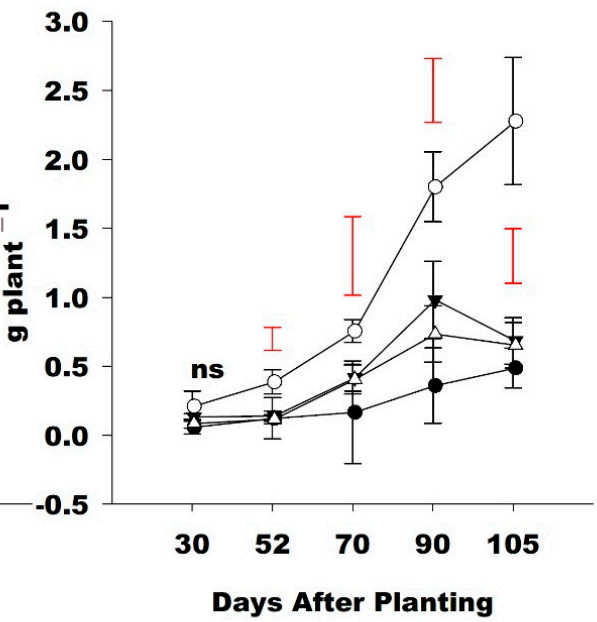

(d) Root : Total Biomass

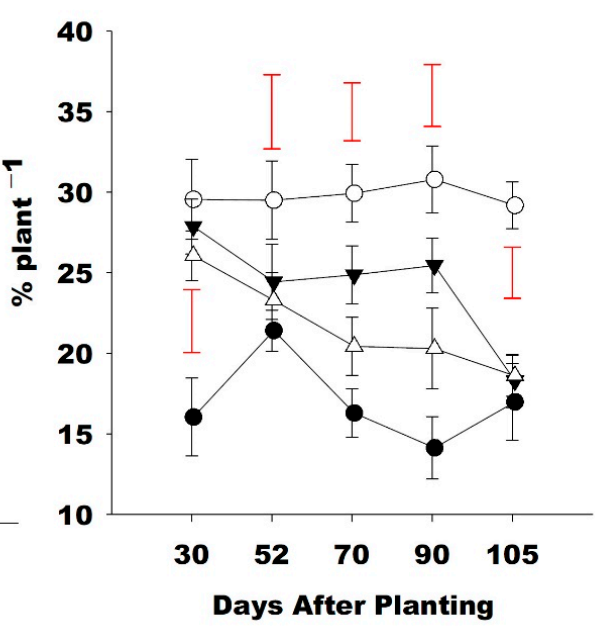

\section{$\bullet$ Untreated $\quad \circ$ Mancozeb $\rightarrow-$ Mefenoxam $\rightarrow-$ Azoxystrobin}

Figure 1. (a) Mean shoot dry-matter production; (b) root dry-matter production; (c) root:shoot ratio; (d) root:total biomass of sugarcane plants treated with fungicides at different sampling intervals in pooled data from 2016 and 2017. Bars represent \pm SE mean; ns: not significant; red-colored vertical bars represent comparison of treatment means at $p \leq 0.05$ (Tukey's HSD test).

Set-root length at the first two harvest dates (30 and 52 DAP) was greater in all three fungicide treatments (mancozeb $>$ azoxystrobin $\geq$ mefenoxam) compared to the untreated check (Figure 3a). At 70 and 90 DAP, set root length was similar among all the treatments. A portion of excised shoot-root images taken in experimental year 2016 are shown in Figure 2. Shoot-root lengths in mancozeb and mefenoxam (mancozeb > mefenoxam) were greater than azoxystrobin and the untreated check (Figure 3b). Azoxystrobin only had significantly greater shoot root lengths than the untreated check at 70 DAP. At 70 DAP, total shoot-root lengths in mancozeb, mefenoxam, and azoxystrobin were $139 \%, 108 \%$, and 52\% higher than untreated plants, respectively. Overall, mancozeb-treated plants had greater fine-root length (Figure 3c) and surface area of roots (Figure 3d) than other treatments. Plotting the root dry weight vs. shoot dry weight to examine the allometric relationship between these variables indicated a potential functional relationship between root biomass allocation relative to shoot biomass $\left(R^{2}=0.84\right)$ (Figure 4$)$. 


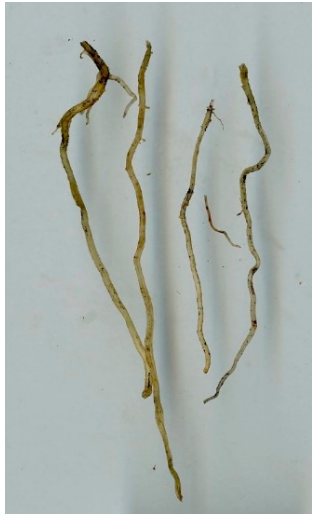

(a)

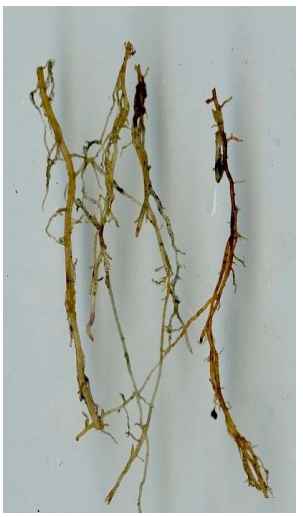

(b)

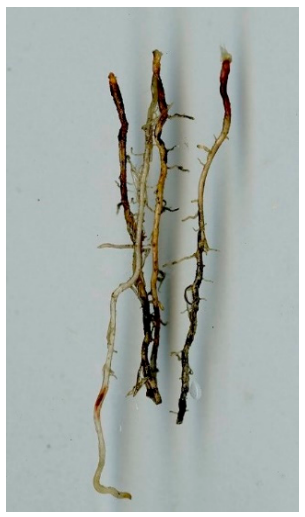

(c)

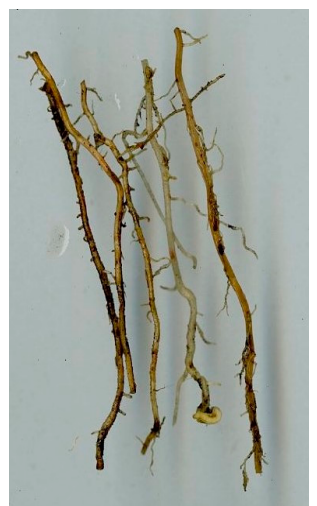

(d)

Figure 2. Sugarcane-seedling shoot roots in Histosols after soil-drench application of fungicides at 70 days after planting (DAP) in experimental year 2016. (a) Untreated; (b) mancozeb; (c) mefenoxam; (d) azoxystrobin.

(a) Set root length

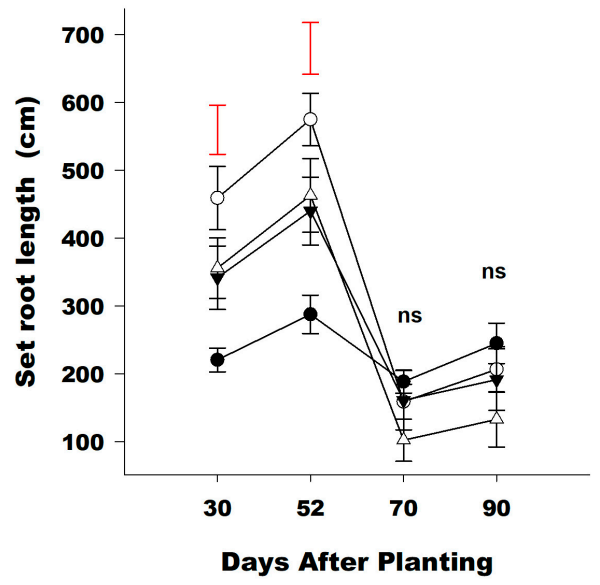

(c) Fine root length

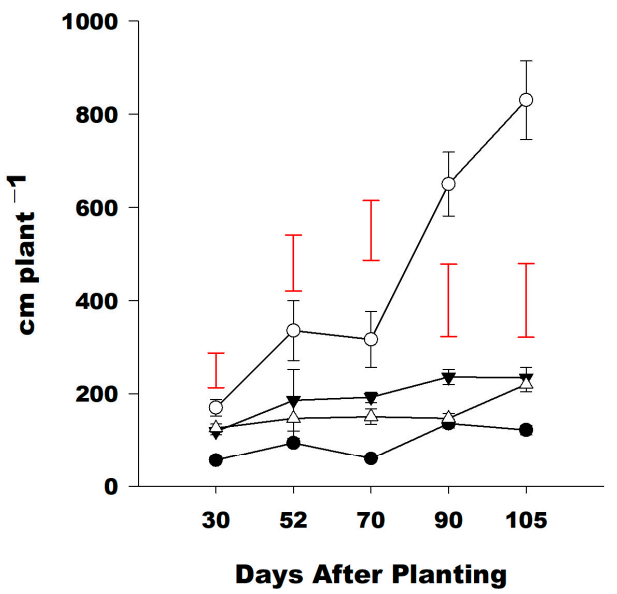

(b) Shoot roots length

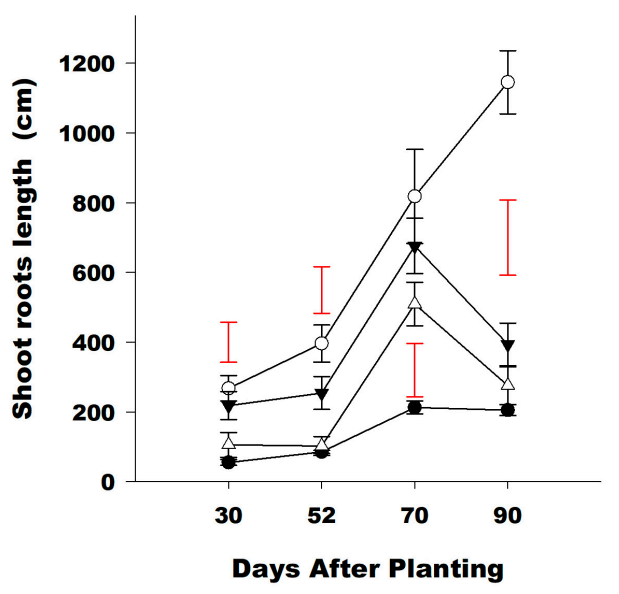

(d) Surface area of roots

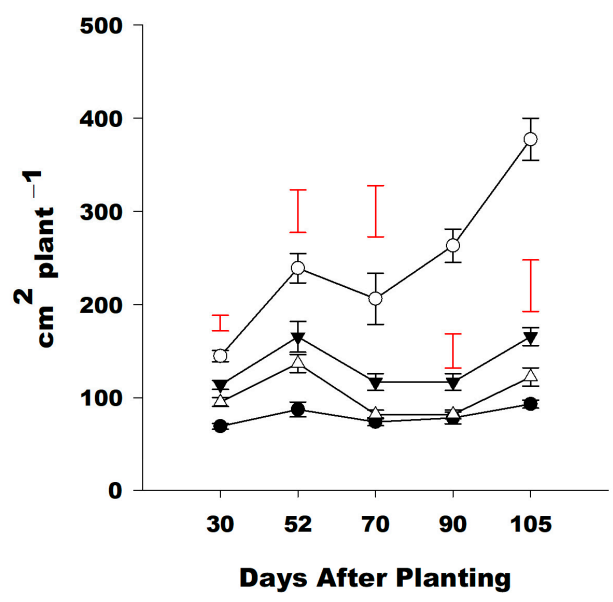

$\rightarrow$ Untreated

$\multimap-$ Mancozeb

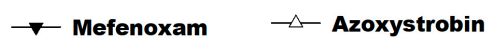

Figure 3. (a) Set-root lengths, (b) shoot-root lengths, (c) fine roots, and (d) surface area of roots of sugarcane plants treated with fungicides at different sampling intervals in pooled data from 2016 and 2017 years. Bars represents \pm SE mean; ns: not significant; Red colored vertical bars represent comparison of treatment means at $p \leq 0.05$ (Tukey HSD test). 


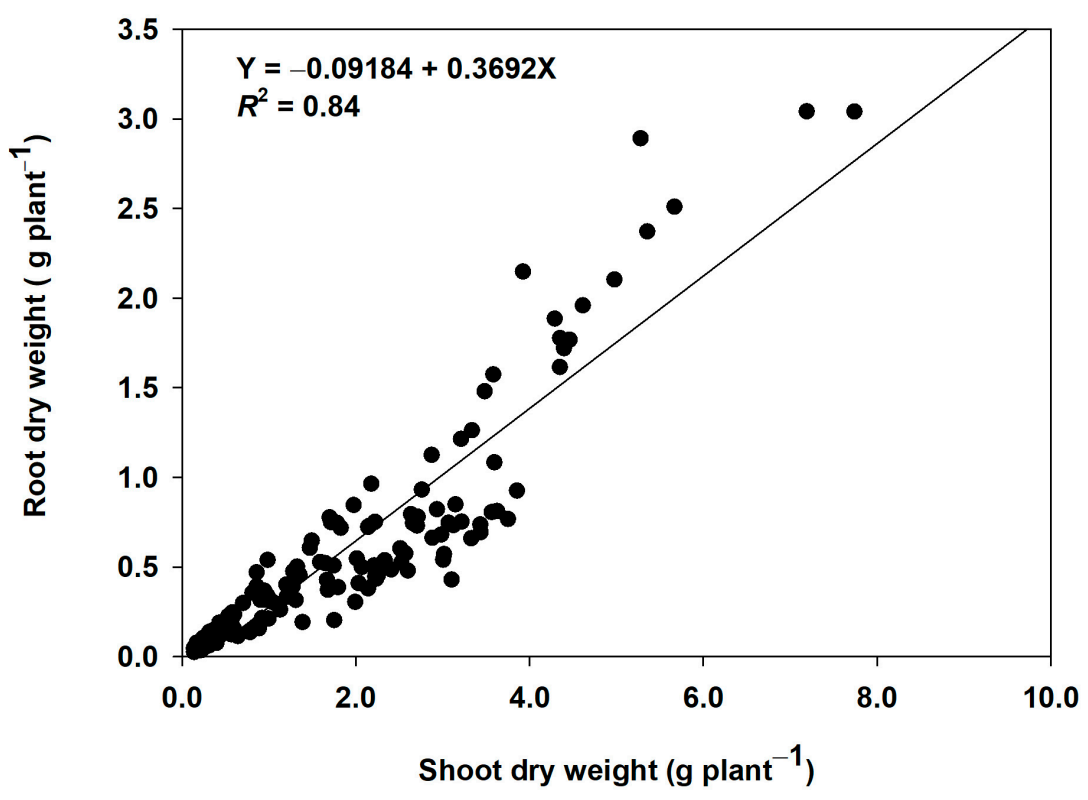

Figure 4. Allometric relationship between shoot dry weight and root dry weight of sugarcane plants during the early growth period.

\subsection{Rhizosphere Microbial Communities}

The impact of fungicides on the abundance of different rhizosphere microbial communities was revealed by PLFA analysis. Overall, 46 PLFAs were detected in the rhizosphere soil samples and 38 were common in all samples. Fungicides reduced the PLFA biomarkers for different functional groups in the rhizosphere soil in comparison to untreated plants, but the differences were not significant in all functional groups (Table 3). Compared to the untreated check, mancozeb significantly reduced all PLFA biomarkers for bacteria and fungi, while mefenoxam reduced the biomarkers for Gram-negative and total bacteria only, and azoxystrobin reduced the biomarkers for fungi only.

\subsection{Mycorrhizal Spore Counts and Root Colonization}

Three species of Glomus (G. mosseae, G. macrocarpum, and G. carum) spores were identified in the rhizosphere of soil under sugarcane cultivation. Average mycorrhizal spore counts ranged from 42 to 46 spores $\mathrm{g}^{-1}$ dry soil weight with no significant differences among treatments (Table 4 ). All three fungicides significantly reduced the percentage of root colonization but total root length colonization by AMF fungi was not impacted by mancozeb. Because of greater root lengths associated with mancozeb-treated plants, total root-length colonization between untreated and mancozeb-treated plants was similar, and it was significantly reduced with mefenoxam and azoxystrobin fungicides. Arbuscular mycorrhizal fungal spores and sugarcane-root colonization by AM fungi are shown in Figure 5. 
Table 3. Abundance of phospholipid fatty acid (PLFA) biomarkers (nmol $\mathrm{g}^{-1}$ dry soil) for different functional groups in rhizosphere soil treated with different fungicides at 70 DAP during experimental year 2017.

\begin{tabular}{|c|c|c|c|c|c|c|c|}
\hline \multirow{2}{*}{ Treatment } & \multirow[b]{2}{*}{ Gram + ve } & \multicolumn{2}{|c|}{ Bacteria } & \multirow[b]{2}{*}{ Total Bacteria } & \multicolumn{2}{|c|}{ Fungi } & \multirow{2}{*}{ F:B Ratio (\%) } \\
\hline & & Gram - ve & Actinomycetes & & Fungi & AMF & \\
\hline Untreated & $60.14 \pm 0.98 \mathrm{a}$ & $76.97 \pm 1.41 \mathrm{a}$ & $43.31 \pm 0.30 \mathrm{a}$ & $179.75 \pm 1.83 \mathrm{a}$ & $6.46 \pm 0.16 a$ & $3.40 \pm 0.03 \mathrm{a}$ & $3.59 \pm 0.05 \mathrm{ab}$ \\
\hline Mancozeb & $53.31 \pm 0.43 b$ & $63.69 \pm 1.74 b$ & $38.19 \pm 1.12 b$ & $155.18 \pm 2.54 b$ & $3.01 \pm 0.31 c$ & $2.07 \pm 0.16 c$ & $1.93 \pm 0.18 c$ \\
\hline Mefenoxam & $56.30 \pm 1.70 \mathrm{ab}$ & $65.84 \pm 1.84 \mathrm{~b}$ & $41.25 \pm 1.70 \mathrm{ab}$ & $163.24 \pm 1.37 b$ & $6.01 \pm 0.08 \mathrm{ab}$ & $3.07 \pm 0.07 \mathrm{ab}$ & $3.70 \pm 0.07 \mathrm{a}$ \\
\hline Azoxystrobin & $59.69 \pm 2.17 \mathrm{a}$ & $69.96 \pm 1.86 \mathrm{ab}$ & $43.62 \pm 0.67 \mathrm{a}$ & $173.27 \pm 1.80 \mathrm{a}$ & $5.19 \pm 0.38 b$ & $2.70 \pm 0.08 b$ & $2.99 \pm 0.21 b$ \\
\hline
\end{tabular}

Values are the means \pm standard error of mean for four replicate rhizosphere-soil samples. Values followed by different letters in a column are significantly different; Tukey's HSD test at $p \leq$ 0.05. (Gram + ve: Gram positive; Gram - ve: Gram negative; AMF: arbuscular mycorrhizal fungi; F:B ratio: Fungi:Bacteria ratio.) 
Table 4. Mean spore counts and percentage and total root-length colonization of AMF in sugarcane with different fungicide soil treatments at 70 DAP during experimental year 2017.

\begin{tabular}{cccc}
\hline Treatment & AMF Spores $\mathbf{~ g}^{\mathbf{- 1}}$ Soil & $\begin{array}{c}\text { Root-Length } \\
\text { Colonization } \mathbf{~ \% )}\end{array}$ & $\begin{array}{c}\text { Total Colonized } \\
\text { Root Length }(\mathbf{c m})\end{array}$ \\
\hline Untreated & $45.28 \pm 1.91 \mathrm{a}$ & $35.42 \pm 3.98 \mathrm{a}(0.363)$ & $169.12 \pm 25.94 \mathrm{a}$ \\
Mancozeb & $42.11 \pm 3.72 \mathrm{a}$ & $8.52 \pm 0.83 \mathrm{~b}(0.101)$ & $124.37 \pm 6.09 \mathrm{ab}$ \\
Mefenoxam & $41.83 \pm 1.81 \mathrm{a}$ & $8.75 \pm 0.91 \mathrm{~b}(0.092)$ & $89.77 \pm 10.47 \mathrm{~b}$ \\
Azoxystrobin & $46.25 \pm 0.96 \mathrm{a}$ & $10.10 \pm 1.76 \mathrm{~b}(0.087)$ & $79.63 \pm 15.23 \mathrm{~b}$ \\
\hline
\end{tabular}

Values are the means \pm standard error of mean for four replicate samples. Figures in parentheses represents arc sintransformed data. Values followed by different letters in a column are significantly different; Tukey's HSD test at $p \leq 0.05$.

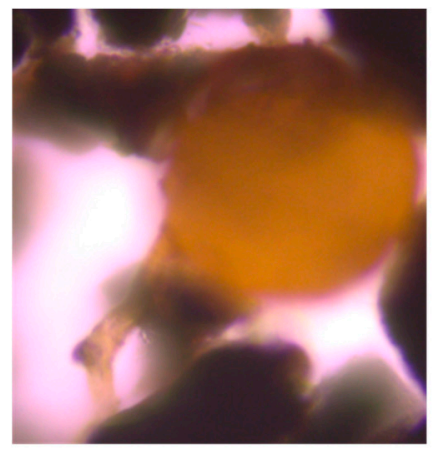

(a)

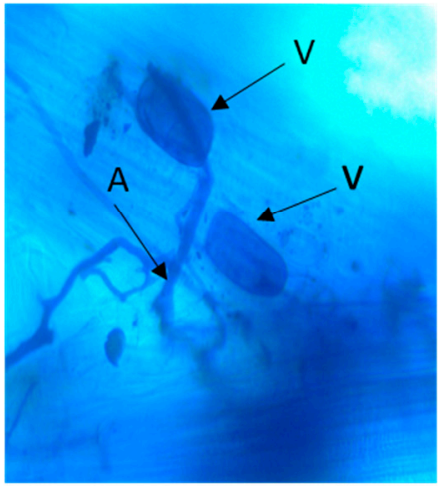

(d)

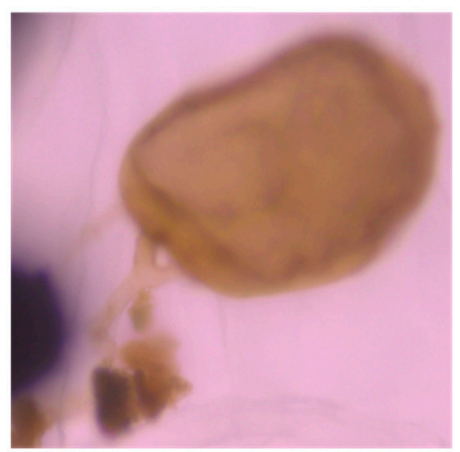

(b)

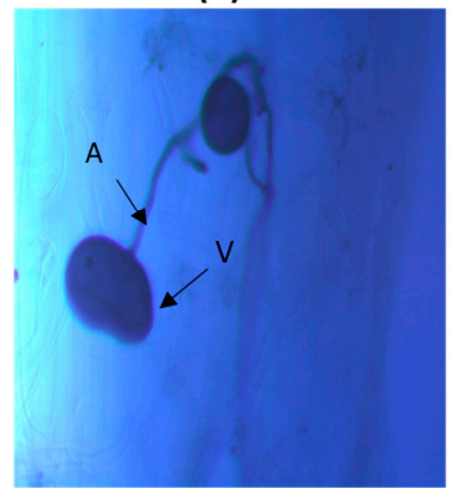

(e)

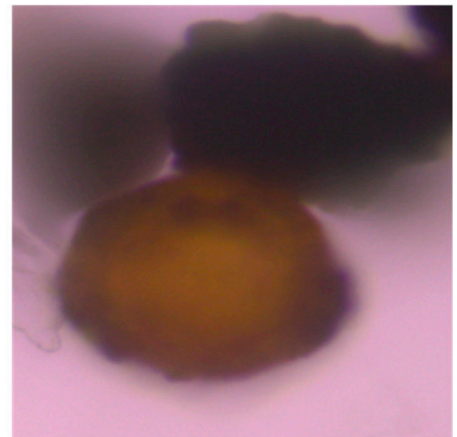

(c)

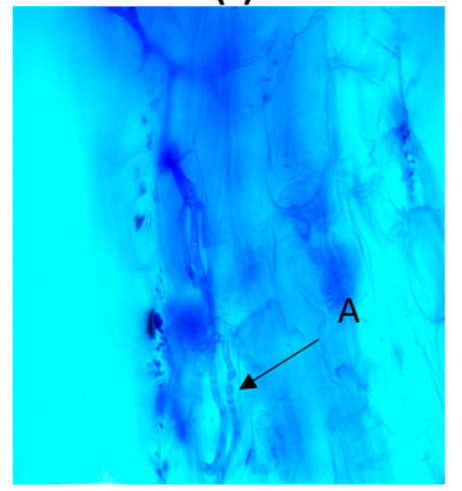

(f)

Figure 5. Arbuscular mycorrhizal fungal spores of different Glomus spp. identified in Histosols and mycorrhizal root colonization under successive sugarcane cultivation in experimental year 2017. (a) G. clarum; (b) G. macrocarpum; (c) G. mosseae; (d-f) sugarcane root infections by arbuscular mycorrhizal fungi images; A: arbuscules, V: vesicles.

\subsection{Tissue Nutrient Concentration and Uptake}

Fungicides had significant effects only on $\mathrm{Si}$ and Fe tissue concentrations of aboveground biomass (Table 5). Mancozeb increased Si and decreased Fe concentrations compared to the untreated check in aboveground biomass. Mefenoxam and azoxystrobin also increased Si tissue concentration compared to the untreated check. Dry-matter production and plant uptake of $\mathrm{N}$ and Zn were greater in mancozeband mefenoxam-treated pots than the untreated check and azoxystrobin (Table 6). Mancozeb increased plant uptake of $\mathrm{P}, \mathrm{Si}$, and $\mathrm{Mg}$, while azoxystrobin increased the uptake of $\mathrm{Cu}$ compared to untreated plants. Fine-root lengths and tissue-nutrient concentrations showed significantly positive correlation with shoot dry matter and silicon uptake $(p \leq 0.01)$, and negative correlations with phosphorus, copper $(p \leq 0.1)$, and iron uptake $(p \leq 0.01)$. Mycorrhizal spore density and root colonization did not show significant correlation with shoot dry weight and nutrient concentrations (Table 7). 
Table 5. Mean tissue concentration of immobile soil nutrients in aboveground biomass under different fungicide soil applications at 70 DAP during experimental year 2017.

\begin{tabular}{|c|c|c|c|c|c|c|c|}
\hline \multirow{2}{*}{ Treatment } & $\mathbf{N}$ & $\mathbf{P}$ & $S i$ & Mg & $\mathrm{Zn}$ & $\mathrm{Cu}$ & $\mathrm{Fe}$ \\
\hline & \multicolumn{4}{|c|}{$\longrightarrow \%$} & \multicolumn{3}{|c|}{$\longrightarrow \mathrm{mg} \mathrm{Kg}^{-1}$} \\
\hline Untreated & $2.34 \pm 0.05 \mathrm{a}$ & $0.23 \pm 0.006 \mathrm{a}$ & $0.64 \pm 0.011 c$ & $0.155 \pm 0.002 \mathrm{a}$ & $19.76 \pm 2.22 \mathrm{a}$ & $3.10 \pm 0.13 \mathrm{ab}$ & $53.41 \pm 1.92 \mathrm{a}$ \\
\hline Mancozeb & $2.58 \pm 0.08 \mathrm{a}$ & $0.21 \pm 0.006 \mathrm{a}$ & $1.27 \pm 0.028 \mathrm{a}$ & $0.148 \pm 0.004 \mathrm{a}$ & $20.87 \pm 2.23 a$ & $2.45 \pm 0.19 \mathrm{~b}$ & $44.13 \pm 2.08 \mathrm{~b}$ \\
\hline Mefenoxam & $2.62 \pm 0.06 \mathrm{a}$ & $0.23 \pm 0.002 \mathrm{a}$ & $0.88 \pm 0.003 b$ & $0.150 \pm 0.001 \mathrm{a}$ & $19.76 \pm 0.88 \mathrm{a}$ & $2.85 \pm 0.14 \mathrm{ab}$ & $47.23 \pm 0.20 \mathrm{ab}$ \\
\hline Azoxystrobin & $2.67 \pm 0.10 \mathrm{a}$ & $0.22 \pm 0.007 \mathrm{a}$ & $0.91 \pm 0.013 \mathrm{~b}$ & $0.145 \pm 0.002 \mathrm{a}$ & $18.60 \pm 0.74 \mathrm{a}$ & $3.48 \pm 0.21 \mathrm{a}$ & $53.87 \pm 1.40 \mathrm{a}$ \\
\hline
\end{tabular}

Values are the means \pm standard error of mean for four replicate plant samples. Values followed by different letters in a column are significantly different; Tukey's HSD test at $p \leq 0.05$.

Table 6. Mean dry-matter production and immobile soil-nutrient uptake by sugarcane plants grown in soil treated with different fungicides at 70 DAP during experimental year 2017

\begin{tabular}{|c|c|c|c|c|c|c|c|c|}
\hline \multirow{2}{*}{ Treatment } & \multirow{2}{*}{ Biomass $\left(\mathrm{g} \mathrm{pot}^{-1}\right)$} & $\mathbf{N}$ & $\mathbf{P}$ & Si & Mg & Zn & $\mathrm{Cu}$ & $\mathrm{Fe}$ \\
\hline & & \multicolumn{4}{|c|}{$\longrightarrow$ mg Plant $^{-1}$} & \multicolumn{3}{|c|}{$\longrightarrow \mathrm{g}$ Plant $^{-1}$} \\
\hline Untreated & $0.92 \pm 0.02 c$ & $21.57 \pm 0.57 \mathrm{~b}$ & $2.13 \pm 0.06 \mathrm{~b}$ & $5.92 \pm 0.07 \mathrm{c}$ & $1.43 \pm 0.04 b$ & $18.13 \pm 1.91 c$ & $2.85 \pm 0.13 b$ & $49.08 \pm 1.19 \mathrm{~b}$ \\
\hline Mancozeb & $1.79 \pm 0.14 \mathrm{a}$ & $46.31 \pm 4.46 \mathrm{a}$ & $3.72 \pm 0.32 \mathrm{a}$ & $22.71 \pm 1.67 \mathrm{a}$ & $2.67 \pm 0.28 \mathrm{a}$ & $36.54 \pm 2.01 \mathrm{a}$ & $4.34 \pm 0.33 \mathrm{ab}$ & $79.37 \pm 8.79 \mathrm{a}$ \\
\hline Mefenoxam & $1.13 \pm 0.22 \mathrm{bc}$ & $29.51 \pm 2.49 \mathrm{ab}$ & $2.62 \pm 0.27 \mathrm{ab}$ & $9.93 \pm 0.96 b c$ & $1.69 \pm 0.15 b$ & $20.89 \pm 2.01 b c$ & $3.23 \pm 0.39 \mathrm{ab}$ & $53.31 \pm 5.29 \mathrm{ab}$ \\
\hline Azoxystrobin & $1.55 \pm 0.28 \mathrm{ab}$ & $41.51 \pm 6.27 a$ & $3.39 \pm 0.52 \mathrm{ab}$ & $14.13 \pm 1.78 \mathrm{c}$ & $2.25 \pm 0.26 \mathrm{ab}$ & $31.27 \pm 4.94 \mathrm{ab}$ & $5.43 \pm 0.92 \mathrm{a}$ & $82.89 \pm 9.95 \mathrm{a}$ \\
\hline
\end{tabular}

Values are the means \pm standard error of mean for four replicate plant samples. Values followed by different letters in a column are significantly different; Tukey's HSD test at $p \leq 0.05$. 
Table 7. Pearson correlation coefficients of sugarcane-root morphological parameters, mycorrhizal spore counts, and root-colonization, dry-matter, and tissue-nutrient concentrations.

\begin{tabular}{ccccccccc}
\hline Variable & Dry Matter & $\mathbf{N}$ & $\mathbf{P}$ & $\mathbf{M g}$ & $\mathbf{S i}$ & $\mathbf{C u}$ & $\mathbf{F e}$ & $\mathbf{Z n}$ \\
\hline Total root length & $0.547^{* *}$ & $0.834^{* * *}$ & -0.488 & -0.305 & $0.925^{* * *}$ & -0.567 & $-0.798^{* * *}$ & 0.158 \\
Fine-root length & $0.689^{* * *}$ & $0.713^{* * *}$ & $-0.592^{*}$ & -0.305 & $0.956^{* * *}$ & $-0.619^{*}$ & $-0.695^{* * *}$ & 0.061 \\
$\begin{array}{c}\text { Surface area of roots } \\
\text { Mycorrhizal spore counts }\end{array}$ & $0.584^{*}$ & $0.722^{* * *}$ & $-0.484^{* *}$ & -0.294 & $0.948^{* * *}$ & $-0.562^{*}$ & $-0.760^{* * *}$ & 0.147 \\
$\begin{array}{c}\text { Colonized mycorrhizal } \\
\text { root length }\end{array}$ & -0.253 & -0.278 & 0.478 & 0.056 & -0.036 & 0.131 & -0.047 & -0.011 \\
& & 0.161 & 0.564 & -0.238 & -0.148 & 0.035 & 0.281 \\
\hline
\end{tabular}

Sample size $n=16$, correlations were significant at ${ }^{*} p \leq 0.1,{ }^{* *} p \leq 0.05,{ }^{* * *} p \leq 0.01$, respectively.

\section{Discussion}

\subsection{Root and Shoot Growth}

Improved early root and shoot growth with soil-applied fungicides supported the assumption that harmful root pathogens (especially fungi) are present in successive soils and negatively affect sugarcane emergence and early growth, with a potential negative effect on yield. Symptoms of a reduced root system and loss of root hairs were either prevented or reduced to some extent with the use of soil fungicides (Figure 2). This study showed that the maintenance of higher root biomass is essential for higher shoot biomass and early tillering in sugarcane. The contribution of root length and root dry weights to shoot dry weights was previously reported for sugarcane early growth in glasshouse studies [45]. Mancozeb effectiveness against yield-decline symptoms at early growth in histosols agrees with previous reports of deleterious soil-fungi association with poor root health and yield decline in other soils $[1,10,12,46-48]$. A possible reason for the low response with mefenoxam may be its selective action against Oomycetes over other root pathogens affecting root health. The lowest response with azoxystrobin may be due to less persistence or quick degradation by microbial communities in the soil.

Allometric relationships in shoot:root dry mass demonstrated that the sugarcane root system must meet the shoot's water and nutrient demands for proper growth. The persistence of root pathogens in sugarcane reduces both root and shoot size during the early growth stage $[4,10,12]$. Higher shoot dry matter and secondary-shoot production in fungicidal treatments show this functional relationship may be present. Similar relationships between root and shoot growth have previously been reported in sugarcane and other cereal grasses [49-51].

\subsection{Rhizosphere Microbial Communities}

PLFA analysis results showed significant reduction in soil fungi as well as different bacterial functional groups with mancozeb application. A similar response was reported in sugarcane monocultures in Australia, where mancozeb at $1200 \mathrm{~kg} \mathrm{ha}^{-1}$ significantly decreased culturable bacterial and fungal populations compared to the untreated check. The effect of mancozeb on microbial communities varied with application rate, soil type, field environment, and laboratory incubation studies [46]. Mancozeb at $10 \mathrm{mg} \mathrm{kg}^{-1}$ soil also reduced bacteria, actinomycete, and fungal populations [52], and the carbon- and nitrogen-mineralization potential of soil [53]. Azoxystrobin reduced the fungi but not the bacterial communities in this study. Adetutu et al. [54] reported that $60 \%$ azoxystrobin was broken down in 21 days and it reduced fungal diversity, while bacterial diversity was unaltered in microcosm-incubation studies involving dark soils. Reduced root colonization of AMF fungi in fungicide treatments (mancozeb and azoxystrobin) might be due to the sensitivity of AMF fungi to these fungicides. Our PLFA results indicated a considerable reduction in abundance of the 16:1w5 AMF biomarker with fungicides. Olsson et al. [55] suggested that the PLFA fraction of 16:1w5 fatty acid originates from AMF mycelium, which means the negative fungicide effect on AMF biomarkers may have indirect preventive effects on mycelial growth in soil. Most of the strobilurin fungicides are spore-germination inhibitors [23], and azoxystrobin might have prevented AMF spore germination. 


\subsection{Tissue-Nutrient Concentration and Uptake}

The uptake of immobile soil nutrients can be related to the configuration of the root system (root length, root diameter, fine-root system, number of tips, etc.) in sugarcane. Despite higher root biomass, fine-root system, and nutrient uptake shown in the aboveground biomass of mancozeb-treated plants (Table 6), lower tissue-nutrient concentrations (especially Fe) (Table 5) was probably due to the growth-dilution effect. In the present study, tissue concentration of silicon $(r=0.956)$ was positively correlated to the fine-root system (diameter $<0.2 \mathrm{~mm}$ ). The soil used in the present study had above 40 ppm of available P. Regardless of mycorrhizal association, P concentration in aboveground biomass was in optimum range. In this study, we are not clear about the beneficial or detrimental role of AMF in early sugarcane growth. However, AMF benefits from a carbon source from sugarcane, and their association is said to be commensalistic. Silicon is deficient in many histosols and is considered a beneficial nutrient, primarily in providing resistance against biotic and abiotic stresses, including some fungal disease-causing pathogens [56]. In general, the total Si content of Histosols ranges from 1 to 2 dag (decagram) $\mathrm{kg}^{-1}$ soil and, owing to the low bulk density of Histosols, concentration of $\mathrm{Si}$ in the root zone may be even lower than these values [57]. Paired-site studies between long-term monocultures and the virgin lands of Australia indicated that $\mathrm{Si}$ was the most depleted nutrient in monoculture soils due to crop exports [58]. The improved Si uptake with mancozeb fungicide may be due to the presence of higher root lengths, a fine-root system, and higher root surface area. Therefore, $\mathrm{Si}$ concentration may be taken as an indicator nutrient for root health improvement in response to fungicidal applications in Histosols.

The results of this study are based on drenching pot soil with different fungicides under greenhouse settings, which may not be a practical and economically viable option for adoption by sugarcane growers. Alternatively, fungicide band application on seed cane stalks laid in the furrows at the time of planting may be a more practical approach for field-scale adoption. Therefore, field research is needed to supplement the results of this study. Although the short growing cycle in this study provided valuable information on initial growth in plant cane, further field research is needed to determine the effect of fungicides over a complete crop cycle, including ratoon crop growth and long-term effects on soil pests and arthropod ground predators.

\section{Conclusions}

In this study, soil-applied fungicides had a positive effect on bud germination and parameters associated with early growth (set, shoot-root, and fine-root lengths, and primary-shoot and secondary-shoot production) of sugarcane plants in successive Histosols. The positive response to fungicides could be attributed to the presence of detrimental soil biota in successive soils associated with poor-root syndrome and reduction in tillering. No significant correlations between the mycorrhizal root colonization of sugarcane plants, spore counts with shoot growth, and immobile soil-nutrient uptake indicated a commensalistic relationship. Significant positive correlations between total and fine-root lengths, surface area of roots with shoot growth, and uptake of nitrogen and silicon show root health is important for early sugarcane growth. Since nitrogen is abundant in Histosols, the plant uptake represents both immobile $\left(\mathrm{NH}_{4}{ }^{+}\right)$and mobile $(\mathrm{NO})$ forms; silicon concentrations in plant tissue may be considered as a better indicator of root health. Additional field research is required to test the efficacy of these fungicides and alternate methods of application in improving early growth in successively planted sugarcane.

Author Contributions: Conceptualization, M.V., H.S.S. and R.N.R.; Methodology, M.V.; Software: H.S.S.; Validation, H.S.S., J.M.M. and R.N.R.; Formal analysis, M.V.; Investigation, M.V.; Resources, H.S.S., J.M.M., R.N.R.; Data Curation, M.V.; Writing-Original Draft Preparation, M.V.; Writing-Review and Editing, H.S.S., J.M.M. and R.N.R.; Visualization, M.V.; Supervision, H.S.S.; Project Administration, H.S.S.; Funding Acquisition, H.S.S.

Funding: This research received no external funding. 
Acknowledgments: We would like to acknowledge the financial support received from the Florida Sugarcane League and the UF Emeritus Endowment matching scholarship award for conducting this research. We thank Abid-Al-Agley for assistance in mycorrhizal assessment and Shangning Ji for assistance in laboratory tissue analyses.

Conflicts of Interest: The authors declare no conflict of interest.

\section{References}

1. Magarey, R.C. Microbiological aspects of sugarcane yield decline. Aust. J. Agric. Res. 1996, 47, $307-322$. [CrossRef]

2. Croft, B.J.; Magarey, R.C. Pathogenic fungi associated with northern poor root syndrome of sugarcane. In Proceedings of the Australian Society of Sugar Cane Technologists, Cairns, Australia, 30 April-4 May 1984; Watson Ferguson and Co: Brisbane, Queensland, 1984; pp. 55-61.

3. Magarey, R.C.; Yip, H.Y.; Bull, J.I. Dematiaceous fungi, a cause of poor root health in sugarcane. In Proceedings of the Australian Society of Sugar Cane Technologists, Bundaberg, Queensland, Australia, 3-6 May 2005; Volume 27, pp. 344-352.

4. Magarey, R.C. Final Report SRDC Project BS73S: Identification of Unknown Root Pathogens Responsible for Sugarcane Yield Decline. Available online: http:/ / elibrary.sugarresearch.com.au/handle/11079/769 (accessed on 23 May 2018).

5. Raid, R.N.; Rott, P. Sugarcane Pineapple Disease or Sugarcane Pineapple Set Rot. Available online: http: / / edis.ifas.ufl.edu/sc005 (accessed on 10 March 2018).

6. Glover, J. The simultaneous growth of sugarcane roots and tops in relation to soil and climate. Sim. Growth Sugarcane Roots Tops Relat. Soil Clim. 1967, 14, 143-159.

7. Garside, A.L.; Berthelsen, J.E.; Pankhurst, C.E.; Blair, B.L.; Magarey, R.C.; D Amato, C.; Bull, J.I.; Blair, B.L.; Bull, J.I. Effect of breaks from sugarcane monoculture and biocides on the growth and yield of a subsequent sugarcane crop. In Proceedings of the Australian Society of Sugar Cane Technologists, Cairns, Australia, 29 April-2 May 2002; PK Editorial Services: Brisbane, Queensland, Australia, 2002; Volume 24, pp. 82-91.

8. Pankhurst, C.E.; Blair, B.L.; D Amato, C.; Bull, J.I.; Magarey, R.C. Quantification of the effects of fumigation and nematicide treatments on the early shoot and root growth of sugarcane in a yield decline soil. In Proceedings of the Australian Society of Sugar Cane Technologists, Mackay, Queensland, Australia, 1-4 May 2001; PK Editorial Services: Brisbane, Queensland, Australia, 2001; pp. 260-267.

9. Pankhurst, C.E.; Magarey, R.C.; Stirling, G.R.; Blair, B.L.; Bell, M.J.; Garside, A.L.; Venture, S.Y.D.J. Management practices to improve soil health and reduce the effects of detrimental soil biota associated with yield decline of sugarcane in Queensland, Australia. Soil Tillage Res. 2003, 72, 125-137. [CrossRef]

10. Magarey, R.C.C.; Yip, H.Y.Y.; Bull, J.I.I.; Johnson, E.J.J. Effect of the fungicide mancozeb on fungi associated with sugarcane yield decline in Queensland. Mycol. Res. 1997, 101, 858-862. [CrossRef]

11. Magarey, R.C.; Bull, J.I. Effect of the dithiocarbamate fungicide mancozeb on sugarcane growth and soil biology in yield decline-affected soils. In Proceedings of the Australian Society of Sugar Cane Technologists, Townsville, Queensland, Australia, 27-30 April 1993; PK Editorial Services: Brisbane, Queensland, Australia, $1999 ;$ p. 32.

12. Hoy, J.W.; Schneider, R.W. Role of Pythium in sugarcane stubble decline: Pathogenicity and virulence of Pythium species. Phytopathology 1988, 78, 1688-1692. [CrossRef]

13. George, E.; Marschner, H.; Jakobsen, I. Role of arbuscular mycorrhizal fungi in uptake of phosphorus and nitrogen from soil. Crit. Rev. Biotechnol. 1995, 15, 257-270. [CrossRef]

14. McCray, J.M.; Rice, R.W.; Luo, Y.; Ji, S. Phosphorus Fertilizer Calibration for Sugarcane on Everglades Histosols. Commun. Soil Sci. Plant. Anal. 2012, 43, 2691-2707. [CrossRef]

15. Lambert, D.H.; Baker, D.E.; Cole, H., Jr. The Role of Mycorrhizae in the Interactions of Phosphorus with Zinc, Copper, and Other Elements. Soil Sci. Soc. Am. J. 1979, 43, 976-980. [CrossRef]

16. Hendrix, J.W.; Jones, K.J.; Nesmith, W.C. Control of pathogenic mycorrhizal fungi in maintenance of soil productivity by crop rotation. J. Prod. Agric. 1992, 5, 383-386. [CrossRef]

17. Johnson, N.C.; Copeland, P.J.; Crookston, R.K.; Pfleger, F.L. Mycorrhizae: Possible Explanation for Yield Decline with Continuous Corn and Soybean. Agron. J. 1992, 84, 387-390. [CrossRef] 
18. Nemec, S. Effects of 11 fungicides on endomycorrhizal development in sour orange. Can. J. Bot. 1980, 58, 522-526. [CrossRef]

19. Groth, D.E.; Martinson, C.A. Increased Endomycorrhizal Infection of Maize and Soybeans After Soil Treatment and Metalaxyl. Plant Dis. 1983, 67, 1377-1378. [CrossRef]

20. Menge, J.A.J.; John, A.M.; Menge, J.A.J. Effect of soil fumigants and fungicides on vesicular-arbuscular fungi. Phytopathology 1982, 72, 1125-1132.

21. USEPA. Pesticide Fact Sheet Number 125: Mancozeb (NTIS PB87-192738); EPA, Office of Pesticide Programs, Registration Division: Washington, DC, USA, 1987; pp. 1-9.

22. Monkiedje, A.; Spiteller, M. Effects of the phenylamide fungicides, mefenoxam and metalaxyl, on the microbiological properties of a sandy loam and a sandy clay soil. Biol. Fertil. Soils 2002, 35, 393-398. [CrossRef]

23. Bartlett, D.W.; Clough, J.M.; Godwin, J.R.; Hall, A.A.; Hamer, M.; Parr-Dobrzanski, B.; Parr-Dobrzanski, B. The strobilurin fungicides. Pest. Manag. Sci. 2002, 58, 649-662. [CrossRef] [PubMed]

24. Balba, H. Review of strobilurin fungicide chemicals. J. Environ. Sci. Health Part B 2007, 42, 441-451. [CrossRef] [PubMed]

25. Matheron, M.E.; Porchas, H. Comparison of five fungicides on development of root, crown, and fruit rot of chile pepper and recovery of Phytophthora capsici from soil. Plant Dis. 2000, 84, 1038-1043. [CrossRef]

26. Pankhurst, C.E.; Stirling, G.R.; Magarey, R.C.; Blair, B.L.; Moody, P.J.; Robotham, B.G.; Braunack, M.V.; Agnew, J. Final Report-SRDC Project Ydv002: Sugar Yield Decline Joint Venture Phase 2 (July 1999-June 2006); BSES Limited and Queensland Department of Primary Industries and Fisheries: Wondunna, Queensland, Australia, 2006; Volume 2.

27. McCray, J.M.; Sandhu, H.S.; Rice, R.W.; Odero, D.C. Nutrient Requirements for Sugarcane Production on Florida Muck Soils. Available online: http://edis.ifas.ufl.edu/pdffiles/SC/SC02600.pdf (accessed on 3 March 2017).

28. Edme, S.J.; Tai, P.Y.P.; Glaz, B.; Gilbert, R.A.; Miller, J.D.; Davidson, J.O.; Dunckelman, J.W.; Comstock, J.C. Registration of 'CP 96-1252' Sugarcane. Crop Sci. 2005, 45, 423-424. [CrossRef]

29. Buyer, J.S.; Sasser, M. High throughput phospholipid fatty acid analysis of soils. Appl. Soil Ecol. 2012, 61, 127-130. [CrossRef]

30. Quideau, S.A.; McIntosh, A.C.S.; Norris, C.E.; Lloret, E.; Swallow, M.J.B.; Hannam, K. Extraction and Analysis of Microbial Phospholipid Fatty Acids in Soils. J. Vis. Exp. 2016, e54360. [CrossRef] [PubMed]

31. Zelles, L. Phospholipid fatty acid profiles in selected members of soil microbial communities. Chemosphere 1997, 35, 275-294. [CrossRef]

32. Wilkinson, S.G. Gram-negative bacteria. In Microbial Lipids; Ratledge, C., Wilkinson, S.G., Eds.; Academic: London, UK, 1988; Volume 1, pp. 299-488.

33. Kroppenstdt, R.M. Fatty Acid and Menaquinone Analysis of Actinomycetes and Related Organisms; Academic Press: Orlando, FL, USA, 1985; ISBN 0122896750.

34. Federle, T.W.; Dobbins, D.C.; Thornton-Manning, J.R.; Jones, D.D. Microbial Biomass, Activity, and Community Structure in Subsurface Soils. Ground Water 1986, 24, 365-374. [CrossRef]

35. Olsson, P.A. Signature fatty acids provide tools for determination of the distribution and interactions of mycorrhizal fungi in soil. FEMS Microbiol. Ecol. 1999, 29, 303-310. [CrossRef]

36. Frostegard, A.; Baath, E. The use of phospholipid fatty acid analysis to estimate bacterial and fungal biomass in soil. Biol. Fertil. Soils 1996, 22, 59-65. [CrossRef]

37. Phillips, J.M.; Hayman, D.S. Improved procedures for clearing roots and staining parasitic and vesicular-arbuscular mycorrhizal fungi for rapid assessment of infection. Trans. Br. Mycol. Soc. 1970, 55, 158-161. [CrossRef]

38. Giovannetti, M.; Mosse, B. An Evaluation of Techniques for Measuring Vesicular Arbuscular Mycorrhizal Infection in Roots. New Phytol. 1980, 84, 489-500. [CrossRef]

39. Gerdemann, J.W.; Nicolson, T.H. Spores of mycorrhizal Endogone species extracted from soil by wet sieving and decanting. Trans. Br. Mycol. Soc. 1963, 46, 235-244. [CrossRef]

40. Jenkins, W.R. A rapid centrifugal-flotation technique for separating nematodes from soil. Plant. Dis. Rep. 1983, 48, 692. [CrossRef]

41. Schenck, N.C.; Norman, C.; Pérez, Y. Manual for the Identification of VA Mycorrhizal Fungi, 3rd ed.; Synergistic Publications: Gainesville, FL, USA, 1990; ISBN 9780962598036. 
42. USEPA. Methods for the Determination of Inorganic Substances in Environmental Samples; USEPA Office of Research and Development: Cincinnati, OH, USA, 1993.

43. USEPA. Methods for the Determination of Metals in Environmental Samples; USEPA Office of Research and Development, Supp. 1, 5/94. Cincinnati, OH, EPA 600/R-94/111; William Andrew: Norwich, UK, 2014; ISBN 9780815513988.

44. Elliott, C.L.; Snyder, G.H. Autoclave-induced digestion for the colorimetric determination of silicon in rice straw. J. Agric. Food Chem. 1991, 39, 1118-1119. [CrossRef]

45. Magarey, R.C.; Grace, D.J. The relationship between root parameters, soil treatment and sugarcane shoot growth in glasshouse experiments. Proc. Aust. Soc. Sugar Cane Technol. 1997, 87-92.

46. Pankhurst, C.E.; Blair, B.L.; Magarey, R.C.; Stirling, G.R.; Garside, A.L. Effects of biocides and rotation breaks on soil organisms associated with the poor early growth of sugarcane in continuous monoculture. Plant. Soil 2005, 268, 255-269. [CrossRef]

47. Garside, A.L.; Bell, M.J. Growth and yield responses to amendments to the sugarcane monoculture: Towards identifying the reasons behind the response to breaks. Crop. Pasture Sci. 2011, 62, 776-789. [CrossRef]

48. Hoy, J.W.; Schneider, R.W. The role of Pythium in sugarcane stubble decline in Louisiana. In Proceedings of the International Society of Sugar Cane Technologists, Sao Paulo, Brazil, 12-21 October 1989; The Organizing Committee of the XX ISSCT Congress: São Paulo, Brazil, 1989; Volume 20, pp. 696-702.

49. Barraclough, P.B.; Leigh, R.A. The growth and activity of winter wheat roots in the field: The effect of sowing date and soil type on root growth of high-yielding crops. J. Agric. Sci. 1984, 103, 59-74. [CrossRef]

50. Smith, J.P.; Lawn, R.J.; Nable, R.O. Investigations into the root: Shoot relationship of sugarcane, and some implications for crop productivity in the presence of sub-optimal soil conditions. Proc. Aust. Soc. Sugar Cane Technol. 1999, 21, 108-113.

51. Troughton, A. Further studies on the relationship between shoot and root systems of grasses. Grass Forage Sci. 1960, 15, 41-47. [CrossRef]

52. Doneche, B.; Seguin, G.; Ribereau-Gayon, P. Mancozeb effect on soil microorganisms and its degradation in soils. Soil Sci. 1983, 135, 361-366. [CrossRef]

53. Černohlávková, J.; Jarkovský, J.; Hofman, J. Effects of fungicides mancozeb and dinocap on carbon and nitrogen mineralization in soils. Ecotoxicol. Environ. Saf. 2009, 72, 80-85. [CrossRef] [PubMed]

54. Adetutu, E.M.; Ball, A.S.; Osborn, A.M. Azoxystrobin and soil interactions: Degradation and impact on soil bacterial and fungal communities. J. Appl. Microbiol. 2008, 105, 1777-1790. [CrossRef] [PubMed]

55. Olsson, P.A.; Bååth, E.; Jakobsen, I.; Söderström, B. The use of phospholipid and neutral lipid fatty acids to estimate biomass of arbuscular mycorrhizal fungi in soil. Mycol. Res. 1995, 99, 623-629. [CrossRef]

56. Ma, J.F. Role of silicon in enhancing the resistance of plants to biotic and abiotic stresses. Soil Sci. Plant Nutr. 2004, 50, 11-18. [CrossRef]

57. Snyder, G.H.; Jones, D.B.; Gascho, G.J. Silicon Fertilization of Rice on Everglades Histosols 1. Soil Sci. Soc. Am. J. 1986, 50, 1259-1263. [CrossRef]

58. Berthelsen, S.; Noble, A.D.; Garside, A.L. Silicon research down under: Past, present, and future. In Silicon in Agriculture; Elsevier Science B.V.: Amsterdam, The Netherlands, 2001.

(C) 2018 by the authors. Licensee MDPI, Basel, Switzerland. This article is an open access article distributed under the terms and conditions of the Creative Commons Attribution (CC BY) license (http:// creativecommons.org/licenses/by/4.0/). 